\title{
Financial and economic aspects of corporate social responsibility
}

\author{
$V . V$. Ilyashenko* \\ Ural State University of Economics, 620144 Ekaterinburg, Russia
}

\begin{abstract}
The article shows the importance of corporate social responsibility (CSR) in ensuring sustainable development of the country. The types of CSR and its features in various states are considered. The author describes the economy of the Russian Federation and its impact on the system of corporate social responsibility in the country. The high profitability of resource-extractive industries and their use of the country's national wealth defines their special role in CSR not only towards their employees through wages and the allocation of social benefits from profit, but also to the society. It is shown that the established country's political system significantly influences the possibility of implementing a system of corporate social responsibility. The author characterizes the significant regulatory and stimulating role of the state in social development through taxation and the structure of government spending. When assessing the financial conditions of CSR, the author analyses the impact of capital outflow on its development. Corporate social responsibility also includes the responsibility of organizations to the environment. The author provides a rating assessment of Russian oil and gas, mining and metallurgical companies openness in terms of environmental responsibility.
\end{abstract}

\section{Introduction}

Corporate social responsibility (CSR) is an integral part of the modern economy and a prerequisite for sustainable development. It has its own characteristics in different countries, on which the combination of private and public interests and the degree of the state's regulatory role in this process depend. The implementation of CSR largely depends on the financial and economic conditions existing in a given state, and it is fully applicable to the Russian Federation. When characterizing corporate social responsibility, it is necessary to take into account the profitability of organizations, distribution of profits, taxation of the country, the structure and dynamics of government spending, capital movement, costs of implementing environmental programs and other economic indicators.

\footnotetext{
*Corresponding author: k-45409@planet-a.ru
} 


\section{Materials and methods}

When researching corporate social responsibility, we used scientific articles devoted to this topic; as well as statistical materials of Rosstat and the Bank of Russia; statutory documents. In writing the article we applied comparison methods, groupings of indicators, expert estimates, index method, etc.

\section{Results and discussion}

The development of corporate property (CSR) is an objective process that reflects the process of concentration and centralization of capital. At the same time, the important role of corporations in the industries that determine the country's economic potential also involves an appropriate level of corporate social responsibility in connection with the high level of profitability of many of these organizations. The objective economic situation in modern Russia demonstrates that enterprises in the raw material sector of the economy play a significant role. So, according to Rosstat, in 2019 the profitability of goods sold, products (work, services) in mining operations was $29.6 \%$, including oil and natural gas extraction $31.9 \%$, in metal ores extraction of $-66.3 \%$. According to the RBC rating, the total revenue of the 500 largest companies in Russia in 2018 amounted to 85.5 trillion. rub. and was $18.2 \%$ more than in 2017 , amounted to $82.3 \%$ of the GDP of the Russian Federation. At the same time, $52.9 \%$ of the total profit of these companies was received by oil and gas sector organizations - 4.9 trillion. rubles, $13.4 \%$ - by mining and metallurgical enterprises, or 1.2 trillion. rub. [1]. It is obvious that the problem of increasing social responsibility is relevant specifically for these industries not only because of the high level of profitability, but also because their activities are associated with the use of national wealth belonging to the entire population.

Corporate social responsibility is understood as the responsibility of an organization for the impact of its activities on society and the environment, which contributes to sustainable development, health and well-being of society; takes into account the interests of interested parties and the state; corresponds to the applicable legislation and is in line with international norms of behavior [2, 3]. If we formulate the definition of corporate social responsibility more briefly, then in the scientific literature this concept is interpreted as the voluntary participation of business in the society development [4]. In accordance with the International Standard ISO 26000 "Guidance on social responsibility" "an integral characteristic of social responsibility is the desire of an organization to include social and environmental factors in its [processes] decision-making and to be accountable for the impact of its decisions and activities on society and the environment." The International Standard ISO 26000 emphasizes the close relationship between social responsibility and sustainable development, which involves meeting the needs of society without compromising the ability of future generations to meet their own needs. At the same time, there are three components of sustainable development - economic, social and environmental, which are interdependent [5]. This does not mean that a high level of corporate social responsibility necessarily ensures sustainable development. The economic development of various countries is cyclical. As society develops, crises become global in nature. This is also noted in the International Standard ISO 26000 "Guidance on social responsibility". Economic and financial crises have the greatest impact on the most vulnerable segments of the population and, therefore, necessitate strengthening the social responsibility of companies. It should not be forgotten that crises may occur in the world, caused not by economic reasons, but by unexpected events, which is observed in modern conditions in connection with the coronavirus pandemic. The spheres of tourism, trade, and 
air transportation found themselves in the most difficult conditions. According to our calculations, based on forecasts of the International Monetary Fund, most of the 12 leading countries in the world, nominal GDP in 2020 will decrease compared to the previous year in Brazil - by $28.4 \%$, India - by $12.4 \%$, in Italy - by $12.4 \%$ and Russia - by $11.5 \%$. And only in China, where the coronavirus epidemic began, the IMF predicts an increase in nominal GDP from $\$ 14.17$ trillion in 2019 to the expected $\$ 15.22$ trillion, i.e. by $7.4 \%$. The Ministry of Economic Development evaluates the economic development of the Russian Federation more optimistically, believing that real GDP in 2020 will decrease by $3.9 \%$, the Central Bank of the Russian Federation tentatively estimates a decline in real GDP this year by $4-5 \%$ with an expected inflation rate of $3.8 \%$ Obviously, in crisis conditions, the determining regulatory role of the state in economic policy in general and in social policy in particular is all the more important.

When analyzing the peculiarities of corporate social responsibility in different countries the author distinguish 2 main types of CSR. Their specificity lies in the degree of independence of organizations in determining the boundaries of their responsibility to society: 1) business itself determines the level of its responsibility to society; 2) state institutions have a decisive influence on business in determining social requirements. In this regard, there are "open" and "hidden" approaches [6,7].

An open approach is largely prevalent in the United States, where organizations independently determine the boundaries of their social responsibility, which is associated with a certain established entrepreneurial culture and the voluntary use of the principles of corporate social responsibility. Government incentives for CSR in the United States consist of the provision of income tax incentives that are used for charitable purposes [8].

The state plays a significant rolein European countries, it determines regulation of the organizations'activities in the CSR area by laws, norms and standards. In particular, we are talking about compulsory health insurance, pensions, environmental protection; consolidating the principles of social responsibility in the Integrated Product Policy, ISO 26000 Social Responsibility Standards, Environmental Audit and Management Scheme. In Japan, the social responsibility of companies is of decisive importance with the important role of the state. The Chinese approach to corporate social responsibility in modern conditions presupposes a focus on the development of social services, increasing taxes and increasing the number of jobs with their qualitative renewal and ensuring the need to benefit society. The Islamic approach to CSR is based on religious moral and ethical norms. It is obvious that the CSR concepts of European countries, Japan and China are most suitable for Russia as a European-Asian country.

The Guidelines of the Global Reporting Initiative (GRI) [8] continue to be the most widespread voluntary corporate reporting standard in the CSRarea. The development of the corporate social responsibility system is evidenced by a significant increase in the publication of non-financial reporting by various companies (social and environmental reports, reports on sustainable development, etc.). So, if in 2011 about 30,000 reports from more than 7,500 organizations were submitted to the International Register of NonFinancial Reports (Corporate Register), at the end of 2018 this figure was 98,000 reports received from more than 16,300 companies [4 ].

The possibility of implementing a system of corporate social responsibility largely depends on the political system that has developed in a given country. So, Naumov A.S. notes that the constitutions of European states stipulate that all types of the country's wealth, regardless of what property they are in, serve the common interests. As for our country, in his opinion, in Russia "reforms continue to be carried out in conditions of preservation of the existing oligarchic political system" and are aimed not at changing this system, but at its modernization. The financial, monetary, foreign economic and social policies of the state and monetary authorities in Russia in modern conditions are such that 
arguments can be made to soften this point of view, but it cannot be completely refuted. In these political and economic conditions, corporate social responsibility in the Russian Federation is objectively implemented to a lesser extent than is required for the development of society [9]. Nevertheless, there are certain successes in this area in Russia. According to the results of the annual research Reputation Institute Global CR RepTrak, in 2018 The LEGO Group, Natura, Microsoft, Google, The Walt Disney Company, BOSCH, Havaianas, Intel, Lavazza and IKEA were recognized as world leaders in CSR. At the same time, two Russian organizations, Gazprom and Sberbank, are among the 500 largest companies in the world [2]. The rating of the Russian Union of Industrialists and Entrepreneurs, compiled in 2018 by the Russian Union of Industrialists and Entrepreneurs, identified such companies as ALROSA, Aeroflot, Gazprom, EuroChem, Zarubezhneft, KAMAZ, MTS, as leaders in the indices of corporate stability, responsibility and openness, NOVATEK, NLMK, Norilsk Nickel, InterRAO, LUKOIL, Metalloinvest, Rosatom, Rosneft, RUSAL, Russian Railways, Russian Networks, Rostelecom, RusHydro, SIBUR, AFK Sistema, Severstal, SUEK, Sberbank, Sakhalin Energy, Tatneft, Transneft, Uralkali [2, p. 432]. Some authors, analyzing the growth rates of sales, net profit and social investments, note that the largest share of social expenses is observed in the metallurgical industry and the electric power industry. At the same time, $85 \%$ of companies plan to allocate funds for charitable programs, which are an integral part of corporate social spending. More than $80 \%$ of organizations either did not change or increased the share of social investments in sales, which positively characterizes CSR practice. At the same time, the authors did not establish a direct relationship between changes in financial indicators and social spending [10].

Based on the definition of CSR, it includes two sides: 1) social responsibility of the corporation to its own employees; 2) social responsibility of the corporation to society. As for the corporation's social responsibility to its own employees, it is determined, firstly, by the level of wages received by the employees of this enterprise and the social benefits that are available to them from the profit of the enterprise; secondly, the fulfillment of social obligations to society. If we analyze in this respect CSR of resource-extracting enterprises, whose social responsibility in Russia should be higher due to their high profitability and is largely necessary for the reasons noted above, then the following forms of its manifestation can be noted. First of all, CSR is realized through a higher level of wages in these industries. So, according to Rosstat, in 2019 the average monthly nominal accrued wages in the Russian Federation amounted to 47,867 rubles. At the same time, in the extraction of minerals it was significantly higher - 89344 rubles, including in the extraction of crude oil and gas - 135,364 rubles, in the extraction of metal ores - 78,520 rubles. As for the public benefit of CSR, it really manifests itself primarily in the charitable activities of these organizations. According to the publications, one of the leaders in the field of public benefit of CSR is the company "Rosneft", which, according to the authors, conducts a unique permanent work in the area of corporate social responsibility. This activity is carried out in several main areas: the development of social infrastructure, support for health care and the development of medicine, financing of educational programs, support for professional and amateur sports, implementation of environmental programs, sponsorship projects in the field of culture [11, 12]. Some authors characterize the relationship of corporate social responsibility with innovation, with corporate ethical standards, and also note its necessity in non-profit organizations $[13,14,15]$.

However, it should be borne in mind that the scale of CSR development in Russia largely depends on the regulatory influence of the state, due to the mentality and characteristics of economic thinking that developed in the 1990s. The main means of increasing corporate social responsibility of organizations in the field of financial policy is 
taxation, which allows to expand the opportunities for organizations to influence the wellbeing of society and the environment through an increase in state budget revenues.

In this regard, the decision of the Government of the Russian Federation to increase the mineral extraction tax (MET) for producers of fertilizers, ferrous and non-ferrous metals, adopted on September 16, 2020, should be positively evaluated. This decision, firstly, largely restores justice in the receipt by the state of natural rent not only from the oil industry, but also from other resource industries, and secondly, it expands the financial possibilities for solving social problems of society. It should be added that an increase in prices for these economic resources and the development of cost inflation in the country may become a negative effect of these tax measures $[16,17]$. In our opinion, the financial possibilities of social responsibility of Russian business in the development of society in the 2000s would have been higher if the progressive scale of personal income tax was used, which is in effect in developed countries. On October 21, 2020, the State Duma of the Federal Assembly of the Russian Federation adopted in the first reading a bill on the introduction of a $15 \%$ personal income tax rate for income over 5 million rubles in a year. However, this decision, firstly, will not significantly increase budget revenues, since the increased rate slightly exceeds the base rate, and secondly, it does not establish the abolition of this tax for the population with low incomes, which usually implies a progressive scale of income tax. In particular, in China, where the maximum tax rate is set at $45 \%$, if a person receives less than 4,000 yuan $(\$ 620)$, then he is exempted from paying income tax.

Opportunities for corporate social responsibility decrease to a certain extent with an increase in capital outflow from Russia, which, in turn, depends on the political and economic situation in the country and the world. According to the Central Bank of the Russian Federation, in the 2000s, the largest capital outflow from Russia was observed in 2008 (- \$ 133.6 billion) and in 2014 (- \$ 154.1 billion). It should be noted that in these years, in comparison with the previous period, the proportion of the population with cash incomes below the subsistence level also increased. In recent years, the minimum indicator of capital outflow from Russia was observed in 2019 (- \$26.7 billion), with the lowest share of the population with money incomes below the subsistence level over the past five years (12.3\%). The Central Bank of the Russian Federation has downgraded the initial forecast for net capital outflow from Russia in 2020 from $\$ 25$ billion to $\$ 53$ billion. The negative consequences of capital outflow include a decrease in tax revenues to the budget of the Russian Federation and a decrease in the possibilities of financing social programs.

In those years when the country's gross domestic product is shrinking and the possibilities for implementing corporate social responsibility programs are decreasing, it is advisable for state bodies to increase the share of financial resources allocated for social purposes from the state budget. So, in 2009, the share of expenditures from the consolidated budget of the Russian Federation on social and cultural events amounted to $52.8 \%$ compared to $51.0 \%$ in 2008. In 2015, when the most significant happened (after the crisis of 2009, ) decrease in real GDP by $3.7 \%$, the share of expenditures from the consolidated budget of the Russian Federation on social and cultural events increased to $57.7 \%$ compared to $54.9 \%$ in 2014 , and from the federal budget - to $36.1 \%$ when $32.8 \%$ in the previous year.

Corporate social responsibility also implies the responsibility of organizations towards the environment. The UN Conference on Sustainable Development (Rio +20$)$ was heldin June 2012, at which the demands of corporations and governments to protect the environment and solve environmental problems were expressed. The National Rating Agency compiled a rating of Russian oil and gas companies in 2014, which allowed to obtain objective information on the level of environmental responsibility of organizations in the oil and gas sector. The best was the joint-stock company Surgutneftegas - one of the 
few oil and gas companies in Russia with the maximum level of information transparency in environmental reporting and publishing data on the costs of environmental protection. The company utilizes associated petroleum gas by generating electricity. The amount of gross economic losses from the irrational use of associated petroleum gas in Russia amounts to 147 billion rubles per year [8]. The rating of openness of Russian oil and gas companies in the field of environmental responsibility, compiled in 2019, ranked Sakhalin Energy (Sakhalin-2) 1st place, Zarubezhneft 2nd place, and Exxon NL (Sakhalin-1) 3rd place. LUKOIL and Surgutneftegaz took 4th and 5th places, as in 2018. Rosneft took 8th place, and Gazprom, which was in 2nd place in 2015, dropped to 6th place in 2018 and 10th in 2019. A similar rating of the transparency of mining and metallurgical companies in the field of environmental responsibility, held among the 40 largest organizations, brought Polyus Gold to 1st place, SDS-coal to 2nd place, Kinross Gold to 3rd place. Of the most famous enterprises, Severstal ranked 6th, ALROSA ranked 8th, Norilsk Nickel ranked 10th, Rusal ranked 17th, EVRAZ ranked 18th, UMMC ranked 20th. Some researchers note that a significant part of companies in the Russian Federation, which have proved themselves in the area of corporate social responsibility to the greatest extent, participating in the implementation of social programs and publishing social reports, carry out their activities with the participation of foreign capital or the state [10].

\section{Conclusion}

We can draw the following conclusions, based on the research conducted in the work:

- When analyzing corporate social responsibility, it is necessary to take into account its features, which are determined by the degree of organizations independence when implementing their responsibility to society. In this regard, there is a distinction between open and hidden approaches to CSR, the use of which differs in various countries.

- Taking into account its economic and moral-ethical conditions, the CSR concepts of European countries, Japan and China are most suitable for Russia as a European-Asian country.

- Companies in the resource sector play a significant role in modern Russia. They have a higher profitability than manufacturing enterprises. An increased level of social responsibility for these organizations is necessary due to the fact that their activities are associated with the use of national wealth that belongs to all members of society.

- Corporate social responsibility of resource-extracting enterprises to their employees is realized through a higher level of wages in these industries. As for CSR towards the society, it is implemented through the charitable activities of these organizations and the costs of environmental protection.

- Taxation is an important means of increasing corporate social responsibility of organizations, which creates the potential to increase the impact of organizations on the welfare of society and the environment through the growth of state budget revenues.

- CSR opportunities are limited to a certain extent by capital outflow from a specific country, also demonstrated in Russia.

- The structure of expenses of the consolidated and federal budgets of the Russian Federation has a significant impact on the implementation of social programs.

- The economic consequence of coronavirus infectionspreading is the economic crisis, which means the need to increase the corporate social responsibility of organizations and strengthen the social role of the state. 


\section{References}

1. O.V. Pokramovich, Economic Sciences, 10 (179), 97 (2019)

2. A.V. Vavilina., T.V. Komarova., I. Velence, R.S. Raikher, Leadership and management, 6 (4), 425 (2019).

3. O.V. Kadnikova, G.R. Lobkov, Leadership and management, 5 (3), 105 (2018)

4. E.L. Pavlov, Economic relations, 9 (4), 2611 (2019)

5. International standard ISO 26000, http://www.ksovok.com/ (2020)

6. K.V. Volnukhin, Economic sciences, 12 (169), 54 (2018)

7. A.A. Morozov, Russian Journal of Entrepreneurship,19 (10), 3119 (2018)

8. V.A. Onuchak, E.N. Levitskaya, Public-private partnership, 3 (3), 221 (2016)

9. A.S. Naumov, Economic sciences, 6 (175), 68 (2019)

10. I.V. Yakhneeva, R.I. Khansevyarov, A.P. Zhabin, E.V. Volkodavova, Russian Journal of Entrepreneurship, 19 (12), 3903 (2018)

11. N.S. Sarakhanova, N.A. Golubkova, Modern management: problems and prospects, 2 , 188 (2016)

12. A.M. Stepanova, Y.N. An, Bulletin of the Omsk Regional Institute, 2(2), 154 (2017)

13. D.F. Kuratko, J.S. McMullen, J.S. Hornsby, C. Jackson, Business Horizons, 60 (3), 271 (2017)

14. I. Martinez-Conesa, P. Soto-Acosta, M. Palacios-Manzano, Journal of Cleaner Production, 142 (4), 2374 (2017)

15. E. Park, K.K. Joon, S.J. Kwon, Journal of Business Research,76, 8 (2017).

16. V.V. Ilyashenko, Macroeconomic and microeconomic aspects of inflation in the transforming economy of Russia (2006)

17. V.V. Ilyashenko, L.N. Kuklina, Economy of the region, 14 (4), 1477 (2018) 